Review

\title{
Modes of Action of Microbially-Produced Phytotoxins
}

\section{Stephen O. Duke * and Franck E. Dayan}

United States Department of Agriculture, Agricultural Research Service, Natural Products Utilization Research Unit, P. O. Box 8048, MS 38677, USA; E-Mail: Franck.Dayan@ars.usda.gov

* Author to whom correspondence should be addressed; E-Mail: Stephen.Duke@ars.usda.gov; Tel.: +1-662-915-1035; Fax: +1-662-915-1035.

Received: 28 July 2011; in revised form: 15 August 2011 / Accepted: 17 August 2011 /

Published: 22 August 2011

\begin{abstract}
Some of the most potent phytotoxins are synthesized by microbes. A few of these share molecular target sites with some synthetic herbicides, but many microbial toxins have unique target sites with potential for exploitation by the herbicide industry. Compounds from both non-pathogenic and pathogenic microbes are discussed. Microbial phytotoxins with modes of action the same as those of commercial herbicides and those with novel modes of action of action are covered. Examples of the compounds discussed are tentoxin, AAL-toxin, auscaulitoxin aglycone, hydantocidin, thaxtomin, and tabtoxin.
\end{abstract}

Keywords: antibiotic; herbicide; phytotoxin

\section{Introduction}

Microbes are a lucrative source of phytotoxins, e.g., [1-10]. The evolutionary pressure for phytotoxin production is obvious with microbial plant pathogens, but many non-pathogenic soil microbes also produce potent phytotoxins, and the role of these compounds in chemical ecology is less clear. An example of the latter case is the production of bialaphos by several Streptomyces species [10,11]. Most of the previous reviews of microbially-produced phytotoxins have focused on aspects of the compounds other than their modes of action. The reviews by Duke et al. [1] and Cutler et al. [12] are exceptions. Any review that focuses on mode of action leaves out many microbial phytotoxins for which we have little or no information on their molecular target site. We also exclude larger phytotoxic peptides (>10 amino acids). 
The mode of action facet of phytotoxins from microbes is overdue for an update, which we provide in this short review. We approach the topic from the standpoint of effects on general plant functions, with details about specific molecular target sites when they are available.

\section{Amino Acid Metabolism}

\subsection{Aminotransferases}

Several microbial secondary compounds either inhibit an amino transferase or appear to have such a mode of action. Cornexistin (Figure 1), a fungal metabolite from Paecilomyces variotii, was patented as a herbicide. The amino transferase inhibitor aminooxyacetate causes identical herbicidal symptoms in duckweed [13]. Cornexistin inhibits aspartate amino transferase activity at high concentrations only after incubation in a plant cellular extract, suggesting that cornexistin is a proherbicide that must be metabolized to an amino transferase inhibitor. Gostatin (Figure 1), a product of Streptomyces sumanensis [14], is a potent amino transferase inhibitor that is phytotoxic [15].

Figure 1. Structures of some microbial compounds known or thought to inhibit amino transferases.

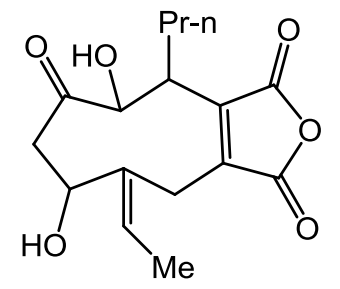

Cornexistin<smiles>NC(CC(N)C(=O)O)CC(N)C(=O)O</smiles>

Ascaulitoxin aglycone<smiles>NC1CNC(C(=O)O)=C(CC(=O)O)C1=O</smiles>

Gostatin<smiles>NC1C=CC=C(C(=O)O)C1</smiles>

Gabaculine

Gabaculin (Figure 1), a product of Streptomyces toyacaenis [16], is an inhibitor of several aminotransferases e.g., [17]. In plants it strongly inhibits glutamate 1-semialdehyde aminotransferase, an enzyme required for 5-aminolevulinate synthesis and thus porphyrin and chlorophyll synthesis [16,18]. This compound will be discussed in more detail under section 11 on porphyrin synthesis.

Ascaulitoxin aglycone (Figure 1), a product of Ascochyta caulina, a fungus being studied as a potential mycoherbicide [19], is a potent phytotoxin that has profound effects on amino acid metabolism as determined by metabolic profiling [20]. Feeding treated plants with most amino acids reversed the effects of the toxin. However, in vitro assays found that the toxin did not inhibit alanine aminotransferase nor alanine:glyoxylate aminotransferase, leading the authors to speculate that it might inhibit another amino transferase or one or more amino acid transporters. 


\section{2. $\beta$-Cystathionase}

Rhizobitoxine (Figure 2) is a phytotoxin produced by some Bradyrhizobium strains [21]. It inhibits $\beta$-cystathionase, which is required for methionine synthesis $[21,22]$. This toxin is phytotoxic enough to have been considered as a commercial herbicide [23]. Since synthesis of the essential plant hormone ethylene is dependent on methionine, one could assume that ethylene synthesis would be greatly inhibited in plants treated with this compound. However, rhizobitoxine also directly inhibits production of ethylene from methionine [24] by inhibition of 1-aminocyclopropane-1-carboxylate synthase [25].

Figure 2. Structure of rhizobitoxine.<smiles>NC(/C=C/COC(=O)CO)C(=O)O</smiles>

Rhizobitoxine

\subsection{Glutamate Synthase}

Acivicin (Figure 3) is a product of Streptomyces sviceu [26] that has been patented as a herbicide [27]. It has not been well studied in plants, but has been well researched as a pharmaceutical. Acivicin is an analogue of glutamine and inhibits a number of glutamine-dependent enzymes, including glutamate synthase [28]. It also inhibits amidophosphoribosyltransferase, phosphoribosylformylglycinamidine synthase, GMP synthase, and $\gamma$-glutamyltranspeptidase [29-31]. Unfortunately, the effects of this toxin on these enzymes in plants are not published.

Figure 3. Structures of glutamate synthase and glutamine synthetase inhibitors from microbes.
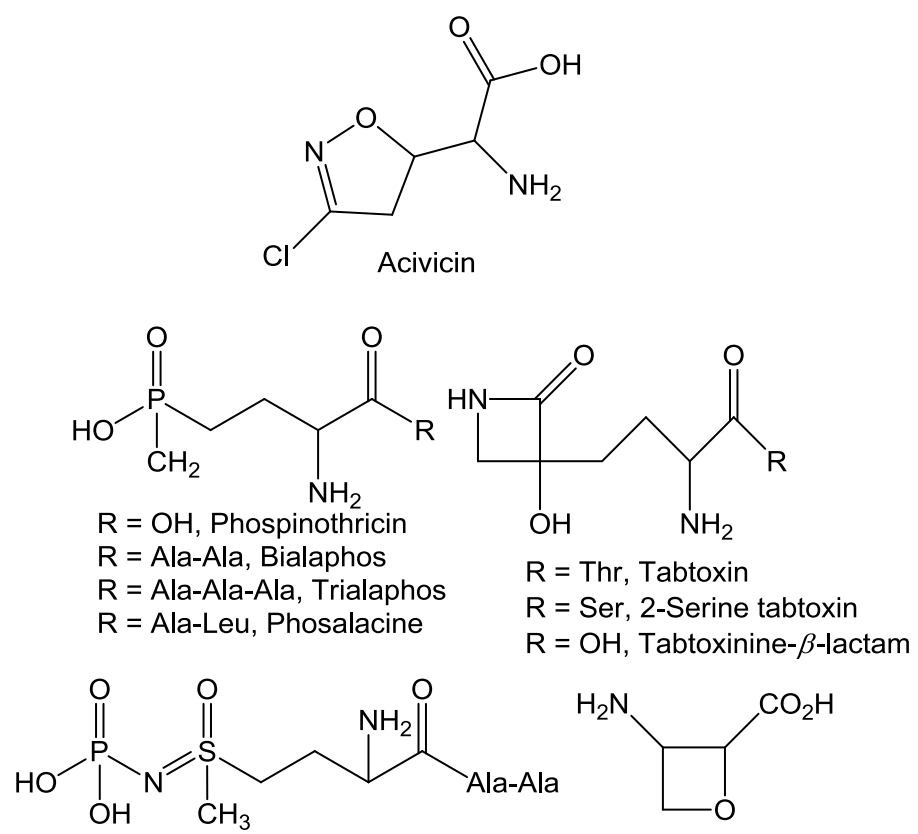


\subsection{Glutamine Synthetase}

Phosphinothricin (Figure 3) and several other microbial products are inhibitors of glutamine synthetase (GS) [32]. This is perhaps the largest collection of microbial compounds that target a particular enzyme. Most of these compounds are of bacterial origin (from either Pseudomonas syringae plant pathovars or from soil-born Streptomyces species). These compounds are all analogues of glutamate, two of them are also produced from inactive di- or tripeptide protoxins (Figure 3).

Streptomyces hygroscopis and S. viridochromogenes both produce bialaphos (Figure 3). This tripeptide does not inhibit GS, but must be metabolized in plants and microbes to L-phosphinothricin, the active GS inhibitor [33]. Inhibition of GS causes accumulation of toxic levels of ammonium, as well as a disruption of amino acid and other primary metabolism [32]. One of the earliest general physiological effects is cessation of photosynthesis [34]. Both bialaphos and phosphinothricin are sold as commercial herbicides. Trialaphos and phosalacine, produced by S. hygroscopicus sp. KSB-1285 and Kitasatosporia phosalacinea, respectively, also release phosphinothricin upon hydrolysis [35,36].

Bialaphos is produced by fermentation. It has a very small market as a herbicide in Japan. Phosphinothricin is sold as a synthetic mixture of L- and D-phosphinothricin sold under several trade names, but given the herbicide common name of glufosinate [37]. The D-isomer is inactive as a GS inhibitor. Glufosinate is one of the most successful commercial herbicides used throughout the world. Oxetin (Figure 3) from Streptomyces sp. OM-2317 [38] and the tripeptide L-( $N^{5}$-phosphono)methionine$S$-sulfoximinyl-L-alanyl-L-alanine from an unclassified strain of Streptomyces [39], are also GS inhibitors. Oxetin is a very weak GS inhibitor. The latter compound is inactive as the tripeptide, but degrades into two known strong GS inhibitors, phosphomethionine sulfoximine and methionine sufoximine.

Several Pseudomonas syringae pathovars produce tabtoxin (Figure 3), a dipeptide prophytotoxin. Tabtoxin is not a GS inhibitor, but it is hydrolyzed in planta to form the potent GS inhibitor tabtoxinine- $\beta$-lactam [40,41]. Analogues of tabtoxin, such as 2-serine-tabtoxin [42], valyl-alanyl-tabtoxin, alanyl-tabtoxin, and alanyl-analyl-tabtoxin [43] have also been reported from various actinomycetes.

\subsection{Ornithine Transcarboxylase}

The product of ornithine transcarboxylase (OCTase) is citrulline, a precursor of arginine. So, inhibition of this enzyme results in loss of arginine production. Phaseolotoxin (Figure 4) is a tripeptide produced by Pseudomonas syringae pv. phaseolicola. Phaseolotoxin is a protoxin, in that peptidases of the plant must convert it to $N^{\delta}-\left(N^{1}\right.$-sulfodiaminophospinhyl)-L-ornithine (PSorn), which is a potent inhibitor of OCTase [44]. 
Figure 4. Phaseolotoxin and PSorn.<smiles>CC(NC(=O)C(CCCCNC(N)=[NH2+])NC(=O)C(C)NC(=O)C(N)CCCNP(N)(=O)NS(=O)(=O)[O-])C(=O)[O-]</smiles>

\section{Cellulose Synthesis}

Thaxtomin A (Figure 5) belongs to a group of cyclic dipeptides (2,5-diketopiperazines) which arise from the condensation of 4-nitrotrytophan and phenylalanine groups. Structure-activity studies determined that the presence of a 4-nitroindole group is necessary to maintain phytotoxicity of these metabolites [45]. These potent toxins are produced by several species of the gram-positive filamentous bacteria in the genus Streptomyces (e.g., S. scabies and S. eubacteria) that cause scab disease in potato and in several taproot crops.

Figure 5. Structure of thaxtomin A.<smiles>CC1C(=O)C(CC2=CNC3C=CC=C([N+](=O)[O-])C23)N(C)C(=O)C1(O)Cc1cccc(O)c1</smiles>

Thaxtomin A

Typical phenotypic responses of plants exposed to thaxtomin A include reduced seedling growth, cell swelling, and lignification of cell walls. Biochemically, thaxtomin inhibits cellulose synthesis. Arabidopsis thaliana seedlings treated with thaxtomin A have lower crystalline cellulose and higher content of pectins and hemicellulose in their cell wall, relative to untreated plants. This is accompanied by an alteration of the expression of genes involved in primary and secondary cellulose synthesis as well as genes associated with pectin metabolism and cell wall remodeling. Thaxtomin A affects the formation of the cellulose synthase complexes on the outside of the plasma membrane, leading to its dissociation from the cortical microtubule cytoskeleton [46]. 


\section{Energy Transfer}

Tentoxin (Figure 6), a cyclic tetrapeptide from the plant pathogen Alternaria alternata, inhibits chloroplast development, which phenotypically manifests itself as chlorotic tissue $[47,48]$. These papers indicate that there is no direct effect of tentoxin on chlorophyll synthesis. Two fundamental processes are linked with this phenotype. This first is inhibition of energy transfer of the chloroplast-localized $\mathrm{CF}_{1}$ ATPase [49,50]. One would think that this process alone could account for the chlorosis, but tentoxin also completely inhibits the transport of nuclear-coded enzyme polyphenol oxidase (PPO) into the plastid, even in etioplasts which should have no $\mathrm{CF}_{1}$ ATPase activity [51]. Without this processing, PPO has no enzyme activity. Inhibition of these two processes seems to be linked, in that both processes are inhibited in vivo in tentoxin-sensitive plant species and not affected in insensitive species [52]. Nevertheless, the coding of the $\beta$ subunit of proton ATPase at codon 83 seems to account for susceptibility of plants to tentoxin [53]. Coding for glutamate at codon 83 correlates for resistance and aspartate coding results in susceptibility to tentoxin. Mutagenesis of Chlamydomonas reinhardtii to change gluamate to aspartate resulted in a change from resistant to susceptible. Later, tentoxin was suggested to exert its effect on chlorophyll accumulation through overenergization of thylakoids [54], but this does not explain the profound effects of the compound on PPO processing in etioplasts without thylakoid membranes. The linkage of the $\beta$ subunit of proton ATPase to PPO processing remains to be explained. Understanding this relationship may help to explain the role of PPO in the plastid, where enzymatic activity is latent $[55,56]$. The true physiological role of PPO in a functional chloroplast is still a mystery.

Figure 6. Microbially-derived phytotoxins that act on energy transfer functions.

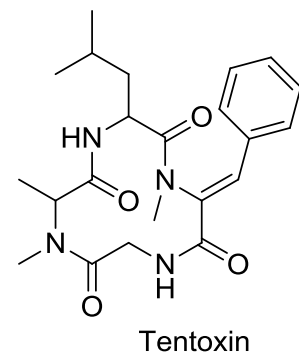<smiles>C/C=C(C)/C=C/C=C/C(OC)C(C)C(OC)C(C)CCc1oc2c(O)c(OC)cc(OC)c2c(=O)c1C</smiles>

Stigmatellin<smiles>COc1ccc(/C=C2\OC(=O)C(Cc3cc(Cl)c4c(c3)OCO4)C2(O)C(C)C)cc1</smiles>

Cyanobacterin<smiles>CC(C)=CCC/C(C)=C/CC/C(C)=C/Cc1c(C)n(O)c2ccccc2c1=O</smiles>

Aurachin C

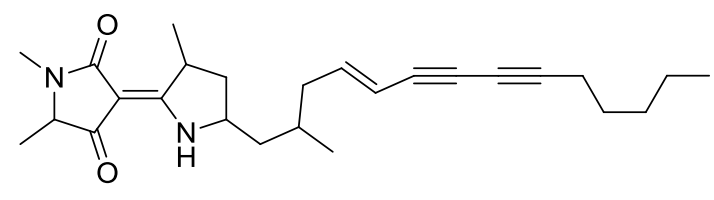

Fischerellin A

Pyridazocidin<smiles>COC1CC(CC2CCC(C)C(C(C)C(=O)O)O2)OC2(O1)OC(C)(C1OC(C)(C3CCC(C4OC(O)(CO)C(C)CC4C)O3)CC1C)CC2C</smiles> 
Nigericin (Figure 6), a product of Streptomyces hygroscopicus, is an uncoupler of photophosphorylation [57]. It inhibits photosynthesis with decreased ATP/ADP ratios, decreased energy quenching, and hyper-reduction of $\mathrm{Q}_{\mathrm{A}}[58]$.

Several microbial phytotoxins inhibit photosynthetic electron transport. These include cyanobacterin, fischerellin A, stigmatellin, and the aurachins (Figure 6). The first two of these compounds are produced by cyanobacteria. Cyanobacterin is a halogenated compound from the freshwater cyanobacterium Scytonema hofmanni that inhibits electron transport of photosystem II [59]. Fischerellin from the cyanobacterium Fischerella muscicola produces fischerellin A that inhibits PSII of green algae and higher plants [60]. Stigmatellin, produced by the myxobacterium Stigmatella aurantica, inhibits photosynthetic electron transport at both the D-1 site of synthetic photosynthetic inhibitors and at the cytochrome b6/f-complex [61]. The aurachins, a group of quinoline compounds from Stigmatella aurantica, also inhibit photosynthesis at the same two sites as stigmatellin [62]. Pyridazocidin (Figure 6), a cationic compound from soil Streptomyces species, causes rapid plant necrosis and chlorosis, much like that of bipyridinium herbicides like paraquat [63]. Studies with isolated chloroplasts showed that its mode of action is exactly like bipyridiniums, diverting electrons from photosystem I to become reduced to a reactive radicle that subsequently generates superoxide radicle, resulting in a cascade of destructive oxidative processes. This is the only natural phytotoxin of which we are aware with this mode of action.

\section{Jasmonic Acid Analogues}

Jasmonic acid (Figure 7) is a plant hormone derived from linolenic acid. It plays a major role in regulating growth and development, as well as responses to both abiotic and biotic stress. Coronatine (Figure 7) is a jasmonate analog produced by Pseudomonas coronafacience [64]. It usurps jasmonate-controlled signaling pathways [65], thereby deregulating many essential processes. The typical symptom of this toxin is chlorosis of developing tissues. Cinnacidin (Figure 7), a product of the fungus Nectria sp. DA060097, has a similar mode of action to coronatine [66].

Figure 7. Jasmonic acid and phytotoxin analogs.

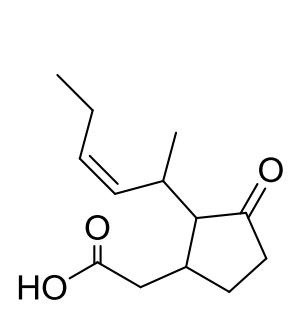

Jasmonic acid

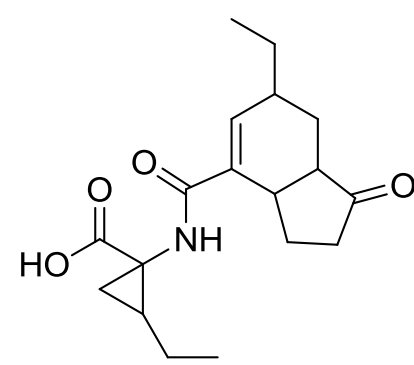

Coronatine

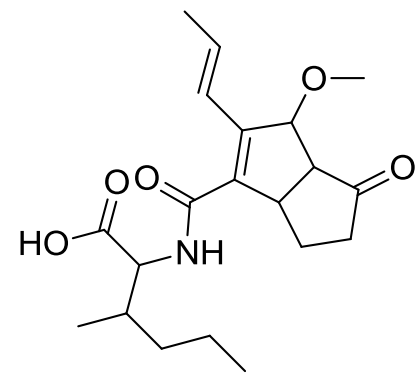

Cinnacidin

\section{Lipid Metabolism}

A series of structurally related fungal metabolites specifically inhibit ceramide synthase (sphinganine- $N$-acyltransferase) in plants. These include several analogues of AAL toxin and fumonisin [67-70] (Figure 8). AAL toxins are produced by Alternaria alternata tomato pathovars and 
fumonisins are produced by Fusarium spp. AAL toxins were originally reported to be host specific, but they are phytotoxic to many plant species, as are their close structural analogues, the fumonisins. These compounds are analogues of the substrate for ceramide synthase, although australifungin is only a weak analog (Figure 8) [70]. When plant tissue is treated with these inhibitors, the sphingolipid precursors and precursor derivative levels are rapidly elevated to concentrations many fold more than found in untreated tissues [71]. This precedes rapid loss of plasma membrane integrity. Others have sought to explain the action of this family of toxins by invoking induction of apoptosis (programmed cell death) [72,73], but the effects are so rapid at even low doses, that this phenomenon seems unlikely to play a direct role except at very low doses. Treatment of plants with the sphingoid base precursors of ceramide synthase causes similar effects to those caused by the inhibitors of ceramide synthase [74]. They cause rapid, light-independent cellular leakage through dysfunction of the plasma membrane. Sphingoid bases also cause generation of reactive oxygen species (ROS) [75] in plant cells. Rapid formation of ROS in the plasma membrane can cause cell death unrelated to apoptosis, whereas slower formation can cause programmed cell death.

Figure 8. Microbial compounds that affect lipid synthesis.

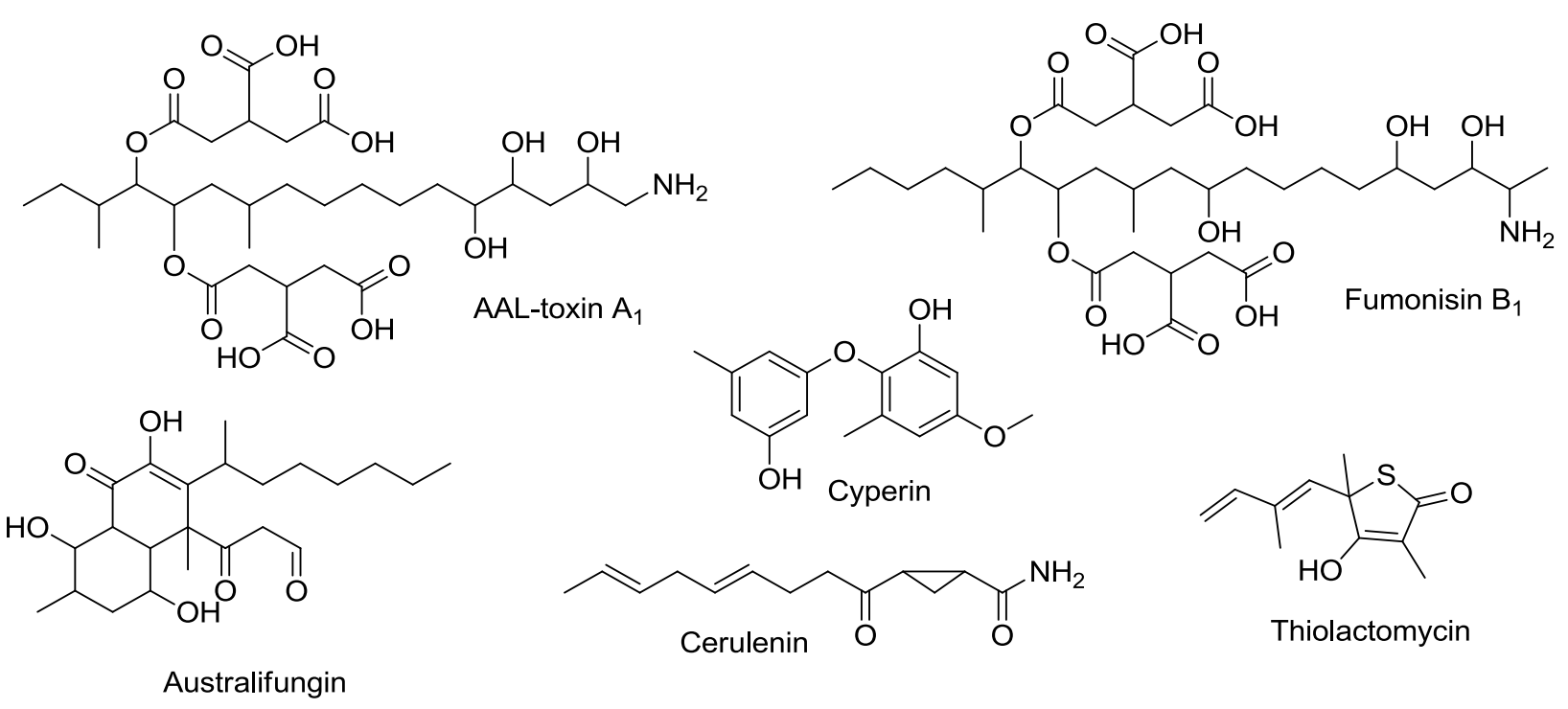

Thiolactomycin (Figure 8) is produced by unidentified species of Norcardia and Streptomyces and is an inhibitor of both plant and animal type II dissociated fatty acid synthetase [76]. It is a very potent inhibitor of incorporation of acetate into fatty acids of chloroplasts [77]. Cerulenin (Figure 8), a product of the fungus Cephalosporium cerulens, inhibits de novo fatty acid synthesis in plastids [78]. Like thiolactomycin, it is an inhibitor of fatty acid synthetases, but it is not as active as an inhibitor [79].

The diphenyl ether compound cyperin (Figure 8), a metabolite of Preussia fleischhakii, Phoma sorghina, and Ascochyta cypericola [80-82], inhibits plant enoyl (acyl carrier protein) reductase (ENR), which is the target site of a synthetic diphenyl ether called triclosan. Inhibition of ENR results in light-independent disruption of membrane integrity [83]. 


\section{Membrane Function}

Syringomycin (Figure 9), from Pseudomonas syringae, is one of the many cyclic lipodepsinonapeptide microbial phytotoxins. Structurally related compounds from the same organism with similar modes of action are syringotoxin and syringostatins [84,85]. These compounds are large molecules that typically have a polar peptide head and a hydrophobic 3-hydroxy fatty acid tail.

Figure 9. Microbially-produced compounds that affect membrane function.

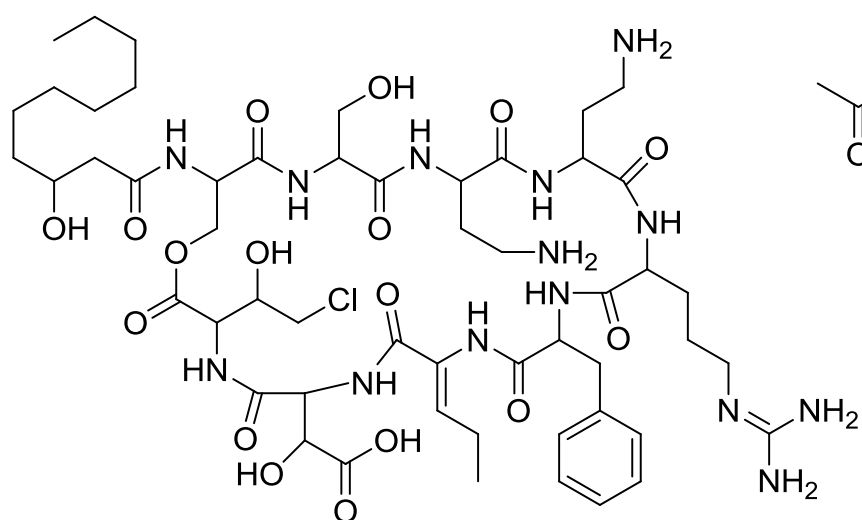

Syringomycin<smiles>C=CC(C)(C)OCC1OC(OC2C3=C(C(C)COC(C)=O)CC(O)C3(C)/C=C3/C(COC)CCC3C(C)C2O)C(O)C(OC(C)=O)C1O</smiles>

Fusicoccin

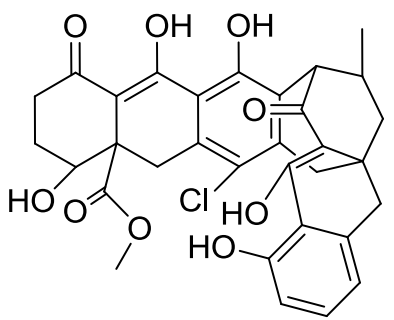

Beticolin<smiles>COc1c(C)c(OCC=C(C)C)cc(CO)c1CO</smiles><smiles>C=C1CCC2C(O)C(C)(O)CCC2(C)C1Cc1c(OC)oc(C)c(C(=O)OC)c1=O</smiles>

Colletotrichin<smiles>CC(C)C(C)NC(=O)C(NC(=O)C(NC(=O)C(CC(C)C(Cl)Cl)NC(=O)C(O)CCCN)C(O)CCCN)C(OC1=C(CC(NC(=O)C(=CCl)NC(=O)C(O)O)C(=O)O)C(=O)C(O)C1)C(C)C</smiles>

Victorin C

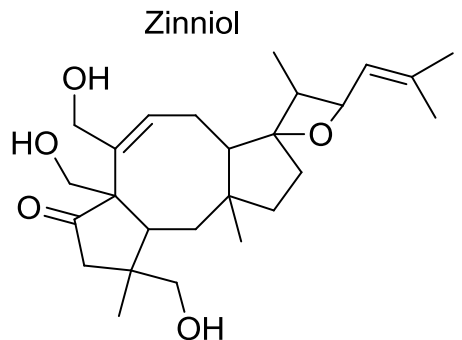

Ophiobolin A<smiles>CCCCCC(O)CC(O)CC(=O)CCCC(=O)CC(O)CC(=O)CCCC(=O)CC(O)CC(=O)CCCCCCC(=O)CC(O)CC(C)=O</smiles>

T-toxin<smiles>CC(=O)OCC12CC(OC(C)=O)C(C)=CC1OC1C(O)C(OC(C)=O)C2(C)C1(C)C</smiles>

T-2 toxin

This hydrophobic tail of varying length (from $\mathrm{C} 10$ to $\mathrm{C} 14$ ) is bound to the $N$-terminal serine residue via an amide bond. The macrocyclic lactone ring is obtained via an ester linkage to the $C$-terminal 4-chlorothreonine. Syringomycin often contains uncommon amino acids such as 2,3-dehydroaminobutyric acid, 3-hydroxyaspartic acid, and 4-chlorothreonine, as well as serine D-isomers and 2,4-diaminobutyric acid [86]. Structure-activity relationship studies reported that chlorination of the molecule is important for biological activity. 
Syringomycin induces rapid necrosis in plant tissues by forming pores that are freely permeable to cations (e.g., $\mathrm{K}^{+}, \mathrm{H}^{+}$, and $\mathrm{Ca}^{2+}$ ) within the plasma membrane. Nanomolar amounts of syringomycin are sufficient to induce loss of membrane integrity and cell death [87].

The beticolins (Figure 9), a yellow group of toxins from Cercospora beticola, self assemble into multimeric ion channels that disrupt membrane function [88,89]. T-toxins (Figure 9) are host-specific, trichothecene phytotoxins from the fungi Cochiobolus heterstrophus, Phyllostica maydis, and Bipolaris maydis. They inhibit mitochondrial respiration by binding an inner mitochondrial membrane protein in sensitive plants, resulting in pore formation, leakage of $\mathrm{NAD}^{+}$, and other ions, as well as subsequent mitrochondrial swelling [90,91]. Fusicoccin (Figure 9) a product of the fungus Fusicoccum (Phomopsis) amygdali irreversibly activates the plant plasma membrane $\mathrm{H}^{+}$-ATPase, leading to inability of stomata to close and subsequent lethal wilting [92,93].

Victorin C (Figure 9), a fungal product of Cochiobolus victoriae, induces a collapse of the mitochondrial transmembrane potential, which results in a mitochondrial membrane transition [94]. It also binds the P protein of the glycine decarboxylase complex of the mitochrondria [95]. All of this has been associated with programmed cell death, but it may also act at the cell surface to cause a hypersensitive response via plasma membrane ion fluxes [95].

Colletotrichin (Figure 9) is a highly phytotoxic compound from several Colletotrichum species, e.g., [96]. Ultrastructurally, the first effect of this compound is disintegration of the plasma membrane, accompanied by massive cellular leakage [97]. The effect is not light dependent and could not be reversed with antioxidants, suggesting that it has a direct effect on the plasma membrane.

Nigericin (Figure 6), a Streptomyces hygroscopicus product is a phytotoxic postassium ionophore [98]. Zinniol (Figure 9), a product of several Alternaria species and one Phoma species, binds plant protoplasts and stimulates $\mathrm{Ca}^{++}$entry into cells [99]. It may act on a specific class of plant calcium channel. There are a number of other compounds produced by plant pathogens that are structurally related to zinniol, but their mode of action has not been determined.

T-2 toxin is a trichothecene that, unlike the other trichothecenes that inhibit protein synthesis, also causes plant plasma membrane leakage of electrolytes at low concentrations [100].

Ophiobolins (Figure 9), tricyclic sesquiterpene phytotoxins from certain species of Bipolaris and other fungal genera, cause many symptoms on plants that were considered to be largely due to effects on the plasma membrane [101]. It effects on maize root ion leakage correlate well with its direct antagonism of calmodulin [102]. Its effects on calmodulin cause inhibition of transport of nuclear-coded proteins into both the mitochondrion [103] and the plastid [104].

\section{Mitotic Disruptors}

Numerous natural products inhibit plant cell mitosis rather directly by interfering with the function of microtubules. However, most all of these are products of plants (e.g., colchicine) [105]. Taxol (Figure 10), a potent mitotic inhibitor, first found in yew (Taxus) species, has subsequently been found to be produced by several endophytic fungi, e.g., [106,107]. In addition to being a potent toxin for mammalian cancer cells, taxol is an effective inhibitor of plant cell mitosis [108]. In both cases it hyperstablizes microtubules, preventing the cycling of tubulin subunits required for microtubule function [109]. 
Figure 10. Structures of some microbially produced plant mitosis disruptors.
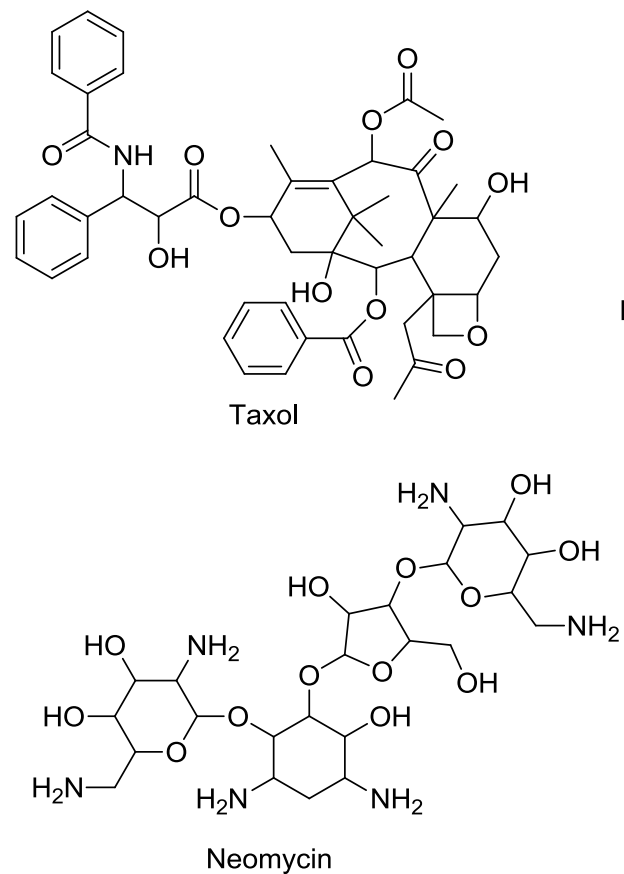

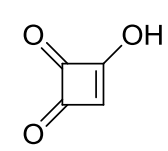

Moniliformin

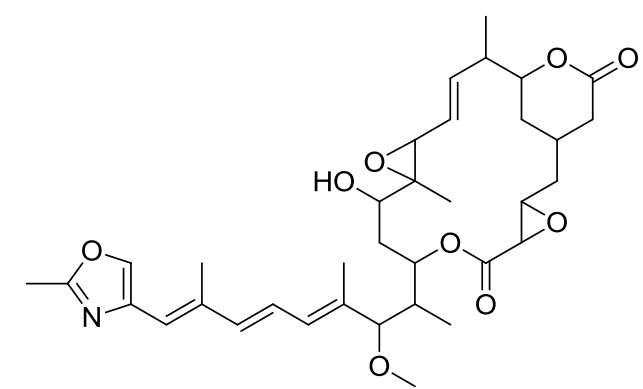

Rhizoxin

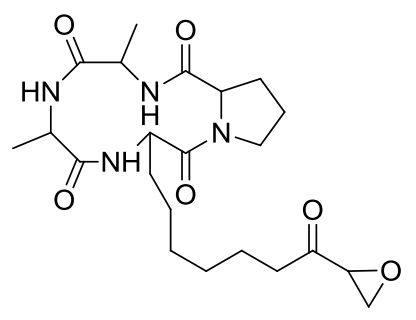

HC-toxin<smiles>C=C1C(=O)C(C)C2(OC(=O)C(=O)NC2Cc2ccccc2)C(/C=C/CC(O)CC(C)CC)C1=O</smiles>

Cytochalasin B

Rhizoxin (Figure 10), a product of a bacterial endosymbiont of the plant pathogen Rhizopus microsporus, binds to $\beta$-tubulin, thereby inhibiting microtubule formation $[110,111]$. These findings were the first reported case of a phytotoxin from a fungus being derived from a bacterial endosymbiont. The producing fungus has a rhizoxin-resistant form of $\beta$-tubulin [112]. Neomycin (Figure 10), an aminoglycoside antibiotic from Streptomyces fradiae, disrupts mitosis in plant cells $[113,114]$. It does this by inhibiting polyphosphoinositide cycling through inhibition of hydrolysis of phosphatidylinositol 4,5-bisphosphate into inositol 1,4,5-triphosphate and 1,2-diacylglycerol. This apparently is the mechanism of phytotoxicity in both higher plants and algae [115].

Moniliformin (Figure 10), a mycotoxin from Fusarium moniliforme, is phytotoxic and arrests mitosis of maize root meristematic cells at the metaphase stage [116]. The mitotic spindle was disrupted, but no direct effect on tubulin has been observed.

Functional actin filaments are required for normal mitosis, as well as other cell functions related to the cell cytoskeleton. Cytochalasins (A-H) (Figure 10) are actin-binding metabolites of several fungal species, such as Phoma exigua and Zygosporium masonii [117]. Binding actin prevents actin polymerization into filaments, thus inhibiting the processes that require actin filaments, such as mitosis and other plant processes [12,118]

HC-toxin (Figure 10), a cyclic tetrapeptide from the maize pathogen Cochliobolus carbonum, inhibits growth and cell division of target plants [119]. Its molecular site of action is histone deacetylase (HDAC). Histones associated with chromosomal DNA become hyperacetylated in treated plants. This condition apparently prevents cell division. HC-toxin may also significantly alter gene expression in ways that would be detrimental to the plant. HC-toxin inhibits this enzyme in all plants and animals and is the basis for new anti-cancer drugs. A number of related fungal compounds are all known or presumed HDAC inhibitors. 


\section{Nucleic Acid Synthesis}

Tagetitoxin (Figure 11) from a pathovar of Pseudomonas syringae inhibits plastid RNA polymerase [120]. This results in a yellow, chlorotic phenotype. It also inibibits RNA polymerase III from animals [121]. Its inhibition is characterized by stalling the elongation complex at several points in the template that are template-dependent [122].

Figure 11. Microbial compounds that inhibit nucleic acid synthesis.

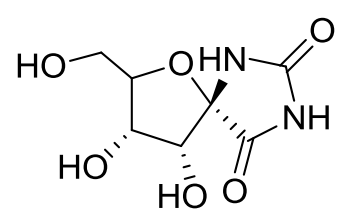

Hydantocidin

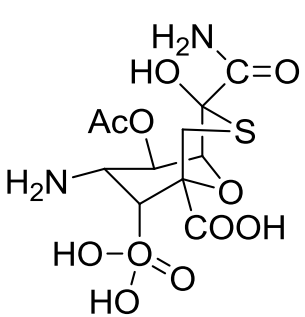

Tagetitoxin

Hydantocidin (Figure 11), a spironucleoside from Streptomyces hygroscopis, is highly phytotoxic [123]. Hydantocidin and a number of synthetic analogues have been patented as herbicides. It is phosphorylated in vivo, and the derivative, 5'-phosphohydantocidin (5PH), inhibits adenylosuccinate synthetase (ASS) [124-127], an enzyme required for purine synthesis. ASS converts IMP to AMP. 5PH inhibits ASS by competitively inhibiting it through binding the IMP substrate binding site, forming a dead-end complex [128]. ASS is also inhibited by ribofuranosyl triazolone, a phytotoxic product of an Actinomadura species [129]. It is a broad spectrum herbicide in greenhouse studies. Guanine monophosphate synthetase, (GMP synthase) converts xanthosine monophosphate to guanosine monophosphate. As mentioned in the amino acid metabolism section, acivicin (Figure 3) is an inhibitor of this enzyme [30].

\section{Photodynamic Compounds}

Cercosporin (Figure 12) is a red fungal toxin that was first isolated in the 1950s from species of the fungal genus Cercospora. This photodynamic pigment is a potent photosensitizer and, in the presence of light and oxygen, it generates singlet oxygen $\left({ }^{1} \mathrm{O}_{2}\right)$ and superoxide $\left(\mathrm{O}^{-\bullet}{ }_{2}\right)$ ions that induce rapid membrane peroxidation and cellular death [130]. Isocercosporin from Scolecotrichum gramminis is also photodynamic [131]. Elsinochromes (Figure 12) from the fungus Elsinoe fawcetti are red pigments of very similar structure to cercosporin [132]. There are several other fungal perylenequinone phytotoxins [133]. They have the same mode of action as cercosporin. 
Figure 12. Structures of some photodynamic microbial phytotoxins.

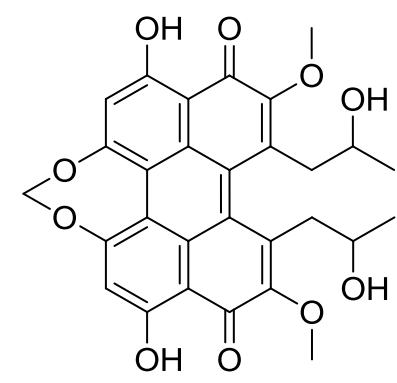

Cercosporin

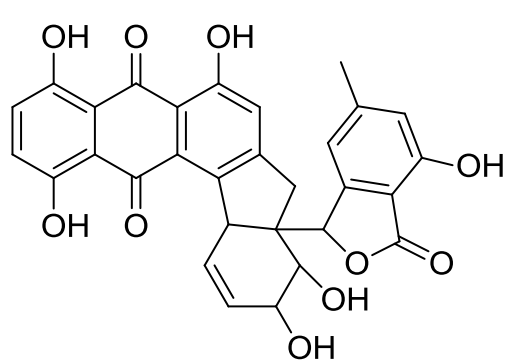

Rubellin D<smiles></smiles>

Elsinochrome A

Cercosporin is a general toxin that will affect the lipid bilayers of any cells including plants, animals, bacteria, and fungi. This compound may also have antiviral activity and inhibit protein kinase C. In plants, tissues and cells treated with cercosporin incur rapid, light-dependent damage to membranes, which is accompanied with an elevation of lipid peroxidation products [134].

Rubellin D (Figure 12), from the fungus Ramularia collo-cygni, is also a phytodynamic pigment that is light-dependent for its activity [135]. This anthraquinone derivative causes singlet oxygen-mediated $\alpha$-linoleic acid peroxidation when exposed to light.

\section{Porphyrin Synthesis}

Cyperin (Figure 8) is a natural diphenyl ether phytotoxin produced by several fungal plant pathogens mentioned in Section 6 [80-82]. At high concentrations, this metabolite inhibits protoporphyrinogen oxidase, a key enzyme in porphyrin synthesis [136]. However, unlike synthetic herbicidal diphenyl ethers that target this enzyme, the mode of action of cyperin is light-independent, causing membrane degradation in the dark. Its main effect as a herbicide is on plant enoyl (acyl carrier protein) reductase (discussed in Section 6).

Gabaculine (Figure 1) is a strong inhibitor of the enzyme glutamate-1-semialdehyde aminotransferase, an enzyme involved in the early porphyrin pathway [137,138]. Inhibition of this enzyme results in stopping synthesis of 5-aminolevulinic acid. By inhibiting porphyrin synthesis, it inhibits both heme and chlorophyll synthesis [139,140], as well as that of the tetrapyrrole phytochrome [141].

\section{Protein Synthesis}

In addition to being a protein synthesis inhibitor of bacteria, the antibiotic streptomycin (Figure 13) inhibits protein synthesis of plastids [142]. It binds to $30 \mathrm{~S}$ ribosomal subunits to cause this effect [143]. Kanamycin and hygromycin (Figure 13), aminoglycoside antibiotics from Streptomyces species, are both phytotoxic [144,145]. They both inhibit protein synthesis by interaction with ribosomes, although kanamycin inhibits prokaryotic-type protein synthesis, while hygromycin inhibits both prokaryotic and eukaryotic protein synthesis [146]. 
Figure 13. Microbial phytotoxins that inhibit protein synthesis.

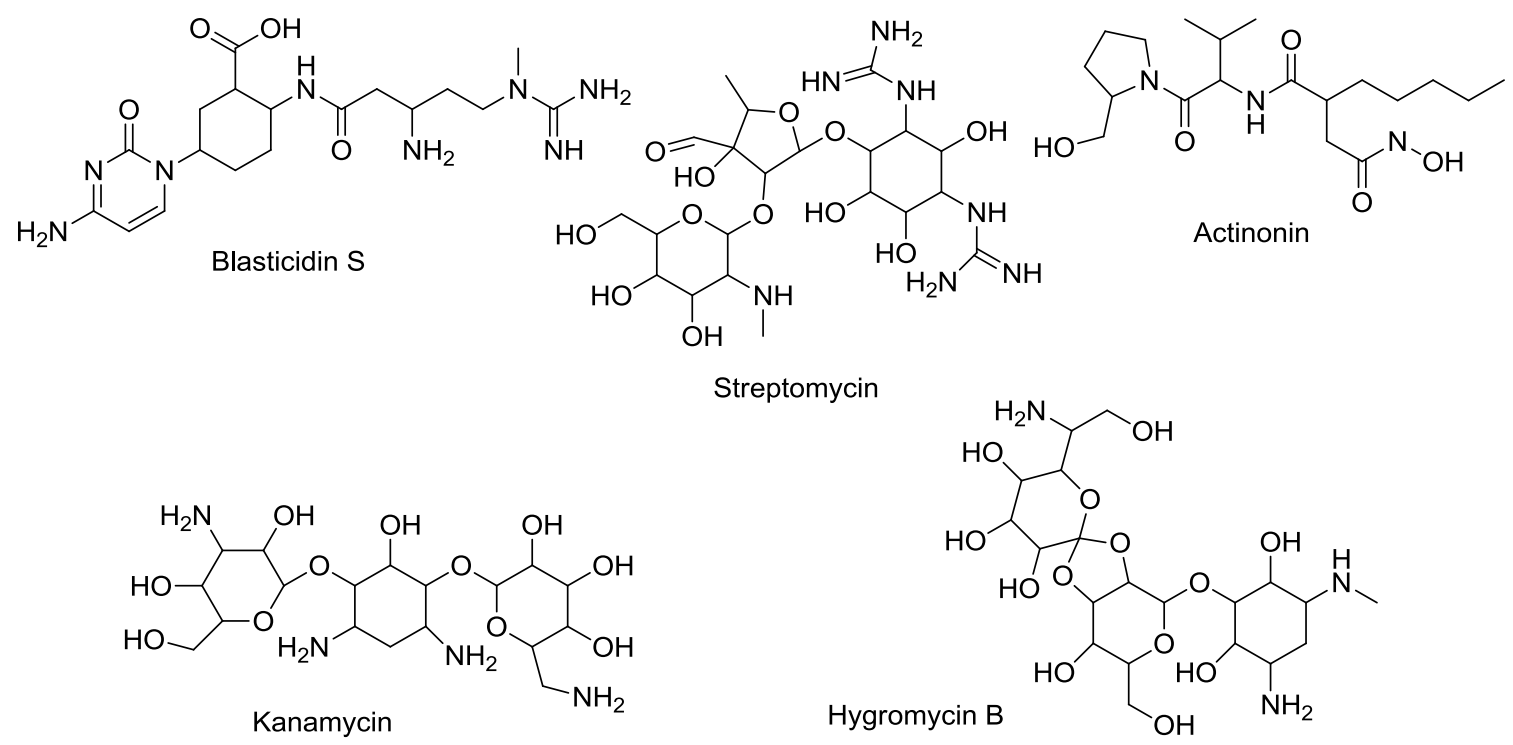

Actinonin (Figure 13), a product of an Actinomyces MG848-hF6 [147], inhibits plastid peptide deformylase $(\mathrm{DEF})$, an enzyme required for $N$-terminal protein processing of plastid-encoded proteins [148,149]. This compound is a non-selective herbicide that results in chlorotic plants. Overexpression of two of three different plant DEFs leads to resistance to actinonin [148-150].

The trichothecenes (see Figure 9 for an example of T-2 toxin), a large class of fungi-produced sesquiterpene mycotoxins, exert most of their effects by inhibiting protein synthesis [12]. They do this apparently by targeting the peptidyltransferase center of mitochondrial ribosomes [151]. One would expect that they would have the same effect on mitochondrial and perhaps plastid ribosomes. Indeed, transgenic modification of wheat with a trichothecene-resistant mitochondrial ribosome subunit, imparts partial resistance to a trichothecene-producing pathogen [152]. Most of the trichothecenes are produced by plant pathogens, including species from genera such as Fusarium, Myrothecium, Trichoderma, and Cephalosporium.

Blasticidin S (Figure 13) is a nucleoside antibiotic that is produced by several Streptomyces species, e.g., $[153,154]$. Blastocidin $S$ is more phytotoxic to dicotyledonous than monocotyledonous species [155]. For example, protein synthesis is more affected in carrot than in rice. It inhibits translation of both eukaryotic and prokaryotic cells by inhibition of peptide bond formation by the ribosome through inhibition of peptidyl transferase [156-158].

\section{Protein Binding}

Compounds with internal disulfide bridges can covalently bind proteins, sometimes inactivating the protein function. They accomplish this by reaction of the disulfide bond with the cysteine components of proteins. Some fungal phytotoxins such as sirodesmin PL (Figure 14) from Leptosphaeria maculans and gliotoxin (Figure 14) have such internal disulfide bridges that conjugate proteins [159-161]. These compounds are also implicated in generation of reactive oxygen species by redox cycling [160]. Such compounds are generally broadly cytotoxic. 
Figure 14. Microbial phytotoxins that directly bind proteins.

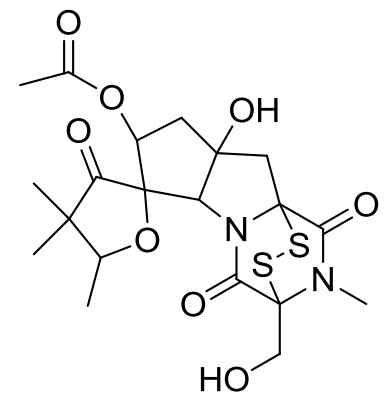

Sirodesmin PL

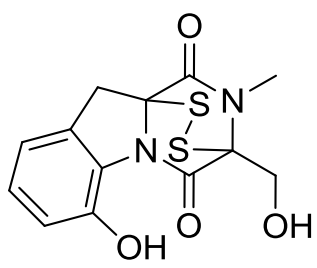

Gliotoxin

\section{Sugar Metabolism}

Anhydro-D-glucitol (Figure 15), produced by the plant pathogenic fungus Fusarium solani, is mildly phytotoxic [162]. When phosphorylated by the plant (Figure 14), it is a close analog of fructose-1,6-bisphosphate, thereby inhibiting fructose-1,6-bisphophate aldolase activity, which is required for production of glyceraldehyde-3-phosphate and dihyroxyacetonephosphate in glycolysis [163].

Figure 15. The inactive (left) and activated (right) forms of anhydro-D-glucitol.<smiles>OCC1OC2(CO)OC1C(O)C2O</smiles>

Anhydro-D-glucitol

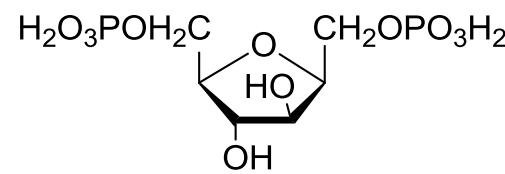

Anhydro-D-glucitol-1,6-bisphosphate

\section{Terpenoid Synthesis}

The macrocidins (Figure 16) from Phoma macrostoma are cyclic tetramic acids. Tetramic acid is an inhibitor of hydoxyphenylpyrutvate dioxygenase (HPPD), but the macrocidins appear to inhibit carotenoid synthesis by a different mode of action [164,165]. HPPD activity is required to produce the cofactor, plastoquinone, of phytoene desaturase, an enzyme involved in carotenoid biosynthesis.

Figure 16. Microbial phytotoxins that inhibit terpenoid synthesis.<smiles>O=CN(O)CCCP(=O)(O)O</smiles>

Fosmidomycin<smiles></smiles>

Macrocidin A<smiles>CC(=CC(=O)O)CC(C)CCCCCC1OC(=O)C1CO</smiles>

Hymeglusin (1233A)

Fosmidomycin (Figure 16), a product of Streptomyces lavendulae [166], is highly phytotoxic, causing extreme chlorosis by inhibition of the non-mevalonic acid pathway, upon which production of 
most of the critical plant terpenoids depend [167,168]. Its enzyme target site is 1-deoxy-D-xylulose 5-phosphate reductoisomerase, an early enzyme in the pathway.

Hymeglusin (Figure 16), also known as 1233A and L-659699, is a phytotoxin produced by several fungal plant pathogens [169,170]. It inhibits 3-hydroxy-3-methylglutaryl coenzyme A synthase of plants and animals $[170,171]$. This enzyme is required for synthesis of certain terpenoids (e.g., sterols) of the mevalonic acid pathway in plants and cholesterol in animals.

\section{Conclusions}

This brief coverage should provide an appreciation for the amazing breadth of microbial phytotoxin structures and modes of action. The number of potential useable herbicide target sites has been a matter of concern among companies involved in herbicide discovery. Molecular methods to discover new target sites have not been particularly fruitful [172]. There are only about twenty molecular sites targeted by the hundreds of commercial herbicide active ingredients, and the last major target site was introduced to the marketplace over twenty years ago. However, it is clear from the many target sites of microbial phytotoxins, that nature has discovered many ways to kill a plant. The growing evolution of weed resistance to existing commercial herbicides has generated a new sense of urgency to discover and develop herbicides with new modes of action [173]. Many of the compounds mentioned in this review have been studied as potential templates for new herbicides with new modes of action. We expect that the growing need for new modes of action will generate a stronger interest in the use of microbial phytotoxins to discover new herbicide target sites.

\section{References}

1. Duke, S.O.; Abbas, H.K.; Amagasa, T.; Tanaka, T. Phytotoxins of microbial origin with potential for use as herbicides. In Crop Protection Agents from Nature: Natural Products and Analogues,

2. Critical Reviews on Applied Chemistry; Copping, L.G., Ed.; Society for Chemical Industries: Cambridge, UK, 1996; Volume 35, pp. 82-113.

3. Berestetskiy, A.O. A review of fungal phytotoxins: From basic studies to practical use. Appl. Biochem. Microbiol. 2008, 44, 453-465.

4. Möbius, N.; Hertwerk, C. Fungal phytotoxins as mediators of virulence. Curr. Opin. Plant Biol. 2009, 12, 390-398.

5. Strange, R.N. Phytotoxins produced by plant pathogens. Nat. Prod. Rep. 2007, 24, 127-144.

6. Mallik, M.A.B. Selective isolation and screening of soil microorganisms for metabolites with herbicidal potential. J. Crop Prot. 2001, 4, 219-236.

7. Abbas, H.K.; Duke, S.O. Phytotoxins from plant pathogens as potential herbicides. Toxin Rev. 1995, 14, 523-543.

8. Cutler, H.G. Microbial natural products that affect plants, phytopathogens, and certain other microorganisms. Crit. Rev. Plant Sci. 1995, 14, 413-444.

9. Evidente, A. Chemical and biological characterization of toxins produced by weed pathogenic fungi as potential natural herbicides. ACS Symp. Ser. 2006, 927, 62-75.

10. Strobel, G.; Kenfield, D.; Bunkers, G.; Sugawara, F.; Clardy, J. Phytotoxins as potential herbicides. Experientia 1991, 47, 819-826. 
11. Barazani, O.; Friedman, J. Allelopathic bacteria and their impact on higher plants. Crit. Rev. Microbiol. 2001, 27, 41-55.

12. Schinko, E.; Schad, K.; Eys, S.; Keller, U.; Wohlleben, W. Phosphinothricin-tripeptide biosynthesis: An original version of bacterial secondary metabolism. Phytochemisry 2009, 70, 1787-1800.

13. Cutler, H.G.; Cutler, S.J.; Matesic, D. Mode of action of phytotoxic fungal metabolites. In Allelopathy: Chemistry and Mode of Action of Allelochemicals; Macías, F.A., Galindo, J.C.G., Molinillo, J.M.G., Cutler, H.G., Eds.; CRC Press: Boca Raton, FL, USA, 2004; pp. 253-270.

14. Amagasa, T.; Paul, R.N.; Heitholt, J.J.; Duke, S.O. Physiological effects of cornexistin on Lemna pauscicostata. Pestic. Biochem. Physiol. 1994, 49, 37-52.

15. Nishino, T.; Murao, S. Isolation and some properties of an aspartate amino transferase inhibitor. Agric. Biol. Chem. 1983, 47, 1961-1966.

16. Nishino, T.; Murao, S.; Wada, H. Mechanism of inactivation of pyridoxal phosphate-linked aspartate transaminase by gostatin. J. Biochem. 1984, 95, 1283-1288.

17. Rando, R.R. Mechanism of the irreversible inhibition of gamma-aminobutyric acid-alphaketoglutaric acid transaminase by the neurotoxin gabaculin. Biochemistry 1977, 16, 4604-4610.

18. Rajaram, V.; Prasuna, P.R.; Savithri, H.S.; Murthy, M.R.N. Structure of biosynthetic $\mathrm{N}$-acetylornithine aminotransferase from Salmonella typhimurium: studies on substrate specificity and inhibitor binding. Proteins 2008, 70, 429-441.

19. Rosellini, D.; Capamaccio, S.; Ferradini, N.; Savo Sardaro, M.L.; Nicolia, A.; Veronesi, F. Non-antibiotic, efficient selection for alfalfa genetic engineering. Plant Cell Rep. 2007, 26, 1035-1044.

20. Evidente, A.; Capasso, R.; Cutignano, A.; Taglialatela-Scafati, O.; Vurro, M.; Zonno, M.C.; Motta, A. Ascaulitoxin, a phytotoxic bis-amino acid $N$-glucoside from Ascochyta caulina. Phytochemistry 1998, 48, 1131-1137.

21. Duke, S.O.; Evidente, A.; Fiore, M.; Rimando, A.M.; Vurro, M.; Chistiansen, N.; Looser, R.; Grossmann, K. Effects of the aglycone of ascaulitoxin on amino acid metabolism in Lemna paucicostata. Pestic. Biochem. Physiol. 2011, 100, 41-50.

22. Owens, L.D.; Guggenheim, S.; Hilton, J.L. Rhizobium-synthesized phytotoxin: And inhibitor of $\beta$-cystathionase in Salmonella typhimurium. Biochim. Biophys. Acta 1968, 158, 219-225.

23. Giovanelli, J.; Owens, L.D.; Mudd, S.H. $\beta$-cystathionase. In vivo inactivation by rhizobitoxine and role of the enzyme in methionine biosynthesis in corn seedlings. Plant Physiol. 1973, 51, 492-503.

24. Owens, L.D. Herbicidal potential of rhizobitoxine. Weed Sci. 1973, 21, 63-66.

25. Owens, L.D.; Lieberman, M.; Kunishi, A. Inhibition of ethylene production by rhizobitoxine. Plant Physiol. 1971, 48, 1-4.

26. Yasuta, T.; Satoh, S.; Minamisawa, K. New assay for rhizobitoxine based on inhibition of 1-aminocyclopropane-1-carboxylate synthase. Appl. Environ. Microbiol. 1999, 65, 849-852.

27. Gould, S.J.; Ju, S. The biosynthesis of acividin and 4-hydroxyacivicin from $\mathrm{N}^{\delta}$-hydroxyornithine. J. Am. Chem. Soc. 1989, 111, 2329-2331. 
28. Brunner, H.G.; Chemla, P.; Dobler, M.R.; O’Sullivan, A.C.; Pachlatko, P.; Pillonel, C.; Stierli, D. Fungicidal properties of acivicin and its derivatives. Am. Chem. Soc. Ser. 2007, 948, 121-135.

29. Conti, P.; Roda, G.; Stabile, H.; Vanoni, M.A.; Curti, B.; De Amici, M. Synthesis and biological evaluation of new amino acids structurally related to the antitumor agent acivicin. Farmaco 2003, 58, 683-690.

30. Natsumeda, Y.; Ikegami, T.; Olah, E.; Weber, G. Significance of purine salvage in circumventing the action of antimetabolites in rat hepatoma cells. Cancer Res. 1989, 49, 88-92.

31. Rodriguez-Suerez, R.; Xu, D.; Veillette, K.; Davison, J.; Sillaots, S.; Kauffman, S.; Hu, W.; Bowman, H.; Martel, N.; Trosok, S.; et al. Mechanism-of-action determination of GMP synthase inhibitors and target validation in Candida albicans and Aspergillis fumigates. Chem. Biol. 2007, $14,1163-1175$.

32. Williams, K.; Cullati, S.; Sand, A.; Biterova, E.I.; Barycki, J.J. Crystal Structure of acivicin-inhibited $\gamma$-glutamyltranspeptidase reveals critical roles for its $C$-terminus in autoprocessing and catalysis. Biochemistry 2009, 48, 2459-2467.

33. Lydon, J.; Duke, S.O. Inhibitors of Glutamine Biosynthesis. In Plant Amino Acids: Biochemistry and Biotechnology; Singh, B.K., Ed.; Marcel Dekker: New York, NY, USA, 1998; pp. 445-464.

34. Wild, A.; Ziegler, C. The effect of bialaphos and ammonium on ammonium-assimilation and photosynthesis. I. Effect on the enzymes of ammonium-assimilation. Z. Naturforsch. 1989, 44, 97-102.

35. Ziegler, C.; Wild, A. The effect of bialaphos and ammonium on ammonium-assimilation and photosynthesis. II. Effect on photosynthesis and photorespiration. Z. Naturforsch. 1989, 44, 103-108.

36. Kato, H.; Nagayama, K.; Abe, H.; Kobayashi, R.; Ishihara, E. Isolation, structure and biological activity of trialaphos. Agric. Biol. Chem. 1991, 55, 1133-1134.

37. Ōmura, S.; Murata, M.; Hanaki, H.; Hinotozawa, T.; Ōiwa, R.; Tanaka, H. Phosalacine, a new herbicidal antibiotic containing phosphinothricin. Fermentation, isolation, biological activity and mechanism of action. J. Antibiot. 1984, 37, 829-835.

38. Copping, L.; Duke, S.O. Natural products that have been used commercially as crop protection agents. A review. Pest Manag. Sci. 2007, 63, 524-554.

39. Ōmura, S.; Murata, M.; Imamura, N.; Iwai, Y.; Tanaka, H.; Furusaki, A.; Matsumoto, T. Oxetin, a new antimetabolite from and ascomycete. Fermentation, isolation, structure and biological activity. J. Antibiot. 1984, 37, 1324-1332.

40. Preuss, D.L.; Scannell, J.P.; Ax, H.A.; Kellett, M.; Weiss, F.; Demny, T.C.; Stempel, A. Antimetabolites produced by microorganisms. VII. L- $\left(N^{5}\right.$-phosphono)methionine-S-sulfoximinylL-alanyl-L-alanine. J. Antibiot. 1973, 26, 261-266.

41. Uchytil, T.F.; Durbin, R.D. Hydrolysis of tabtoxins by plant and bacterial enzymes. Experientia 1980, 36, 301-302.

42. Lanston-Unkefer, P.L.; Robinson, A.C.; Knight, T.J.; Durbin, R.D. Inactivation of pea seed glutamine synthetase by tabtoxinine- $\beta$-lactam. J. Biol. Chem. 1987, 262, 1608-1613.

43. Taylor, P.A.; Schnoes, H.K.; Durbin, R.D. Characterization of chlorosis-inducing toxins from a plant pathogenic Pseudomonas species. Biochim. Biophys. Acta 1972, 286, 107-117. 
44. Sato, Y.; Watabe, H.O.; Ueno, S.; Miyadoh, S.; Koyama, M. SF2448 A, B, and C, new herbicidal peptide antibiotics related to tabtoxin. Sci. Rep. Meiji Seika Kaisha 1990, 29, 14-20.

45. Templeton, M.D.; Reinhardt, L.A.; Collyer, C.A.; Mitchell, R.E.; Cleland, W.W. Kinetic analysis of the L-ornithine transcarbamolylase from Pseudomonas savastanoi pv. phaseolicola that is resistant to the transition state analogue $(R)-N^{\delta}$-( $N^{\prime}$-sulfodiaminophosphinyl)-L-ornithine. Biochemistry 2005, 44, 4408-4415.

46. King, R.R.; Calhoun, L.A. The thaxtomin phytotoxins: sources, synthesis, biosynthesis, biotransformation and biological activity. Phytochemistry 2009, 70, 833-841.

47. Bischoff, V.; Cookson, S.J.; Wu, S.; Scheible, W.-R. Thaxtomin A affects CESA-complex density, expression of cell wall genes, cell wall composition, and causes ectopic lignification in Arabidopsis thaliana seedlings. J. Exp. Bot. 2009, 60, 955-965.

48. Halloin, J.M.; De Zoeten, G.A.; Gaard, G.R.; Walker, J.C. Effects of tentoxin on chlorophyll synthesis and plastid structure in cucumber and cabbage. Plant Physiol. 1970, 45. 310-314.

49. Duke, S.O.; Wickliff, J.L.; Vaughn, K.C.; Paul, R.N. Tentoxin does not cause chlorosis in greening mung bean leaves by inhibiting photophosphorylation. Physiol. Plant. 1982, 56, 387-398.

50. Selman, B.R.; Durbin, R.D. Evidence for a catalytic function of the coupling factor 1 protein reconstituted with chloroplast thylakoid membranes. Biochim. Biophys. Acta 1978, 502, 29-37.

51. Reimer, S.; Selman, B.R. Tentoxin-induced energy-independent adenine nucleotide exchange and ATPase activity with chloroplast coupling factor 1. J. Biol. Chem. 1978, 253, 7249-7255.

52. Vaughn, K.C.; Duke, S.O. Tentoxin stops the processing of polyphenol oxidase into an active enzyme. Physiol. Plant. 1984, 60, 257-261.

53. Duke, S.O. Tentoxin effects on variable fluorescence and P515 electrochromic absorbance changes in tentoxin-sensitive and -resistant plant species. Plant Sci. 1993, 90, 119-126.

54. Avni, A.; Anderson, J.D.; Hollan, N.; Rochaix, J.D.; Gromet-Elhanan, Z.; Edelman, M. Tentoxin sensitivity of chloroplasts determined by codon 83 of $\beta$ subunit of proton ATPase. Science 1992, 257, 1245-1247.

55. Holland, N.; Evron, Y.; Jansen, M.A.K.; Edelman, M.; Pick, U. Involvement of thylakoid overenergization in tentoxin-induced chlorosis in Nicotiana spp. Plant Physiol. 1997, 114, 887-892.

56. Trebst, A.; Depka, B. Polyphenol oxidase and photosynthesis research. Photosynthesis Res. 1995, 46, 41-44.

57. Vaughn, K.C.; Lax, A.R.; Duke, S.O. Polyphenol oxidase: The chloroplast oxidase with no established function. Physiol. Plant. 1988, 72, 659-665.

58. Shavit, N.; San Pietro, A. $\mathrm{K}^{+}$-dependent uncoupling of photophosphorylation by nigericin. Biochim. Biophys. Acta 1967, 28, 277-283.

59. Quick, P.; Scheibe, R.; Stitt, M. Use of tentoxin and nigericin to investigate the possible contribution of $\Delta \mathrm{pH}$ to energy dissipation and the control of electron transport in spinach leaves. Biochim. Biophys. Acta 1989, 974, 282-288.

60. Lee, E.-S.J.; Gleason, F.K. A second algicidal natural product from the cyanobacterium, Scytonema hofmanni. Plant Sci. 1994, 103, 155-160. 
61. Srivastava, A.; Juttner, F.; Strasser, R.J. Action of the allelochemical, fischerellin A, on photosystem II. Biochim. Biophys. Acta Bioenerg. 1998, 1365, 326-336.

62. Oettmeier, W.; Godde, D.; Kunze, B.; Hoefle, G. Stigmatellin. A dual type inhibitor of photosynthetic electron transport. Biochim. Biophys. Acta Bioenerg.1985, 807, 216-219.

63. Oettmeier, W.; Dostatni, R.; Majewski, C.; Hoefle, G.; Fecker, T.; Kunze, B.; Reichenbach, H. The aurachins, naturally occurring inhibitors of photosynthetic electron flow through photosystem II and cytochrome b6/f-complex. Z. Naturforsch. 1990, 45C, 322-328.

64. Gerwick, B.C.; Fields, S.S.; Graupner, P.R.; Gray, J.A.; Chapin, E.L.; Cleveland, J.A.; Heim, D.R. Pyridazocidin, a new microbial phytotoxin with activity in the Mehler reaction. Weed Sci. 1997, 45, 654-657.

65. Ichihara, A.; Shiraishi, K.; Sato, H.; Sakamura, S.; Nishiyama, K.; Sakai, R.; Furusaki, A.; Matsumoto, T. The structure of coronatine. J. Am. Chem. Soc. 1977, 99, 636-637.

66. Block, A.; Schmelz, E.; Jones, J.B.; Klee, H.J. Coronatine and salicylic acid: the battle between Arabidopsis and Pseudomonas for phytohorome control. Mol. Plant Pathol. 2005, 6, 79-83.

67. Irvine, N.M.; Yerkes, C.N.; Graupner, P.R.; Roberts, R.E.; Hahn, D.R.; Pearce, C.; Gerwick, B.C. Synthesis and characterization of synthetic analogs of cinnacidin, a novel phytotoxin from Nectria sp. Pest Manag. Sci. 2008, 64, 891-899.

68. Abbas, H.K.; Duke, S.O.; Tanaka, T. Phytotoxicity of fumonisins and related compounds. J. Toxicol.-Toxin Rev. 1993, 12, 225-251.

69. Abbas, H.K.; Duke, S.O.; Shier, W.T.; Riley, R.T.; Kraus, G.A. The Chemistry and Biological Activities of the Natural Products AAL-Toxin and the Fumonisins. In Natural Toxins 2. Structure, Mechanism of Action, and Detection; Singh, B.R., Tu, A.T., Eds.; Plenum: New York, NY, USA, 1996; pp. 293-308.

70. Abbas, H.K.; Duke, S.O.; Shier, W.T.; Duke, M.V. Inhibition of Ceramide Synthesis in Plants by Phytotoxins. In Advances in Microbial Toxin Research and Its Biotechnological Exploitation; Upadhyay, R.K., Ed.; Kluwer Academic/Plenum Pub.: London, UK, 2002; pp. 211-229.

71. Abbas, H.K.; Duke, S.O.; Merrill, A.H.; Wang, E.; Shier, W.T. Phytotoxicity of australifungin, AAL-toxins and fumonisin $\mathrm{B}_{1}$ to Lemna pausicostata. Phytochemistry 1998, 47, 1509-1514.

72. Abbas, H.K.; Tanaka, T.; Duke, S.O.; Porter, J.K.; Wray, E.M.; Hodges, L.; Sessions, A.E.; Wang, E.; Merrill, A.H.; Riley, R.T. Fumonisin and AAL-toxin-induced disruption of sphingolipid metabolism with accumulation of free sphingoid bases: Involvement in plant disease. Plant Physiol. 1994, 106, 1085-1093.

73. Lincoln, J.E.; Richael, C.; Overduin, B.; Smith, K.; Bostock, R.; Gilchrist, D.G. Expression of the antiapoptotic baculovirus p35 gene in tomato blocks programmed cell death and provides broad-spectrum resistance to disease. Proc. Natl. Acad. Sci. USA 2002, 99, 15217-15221.

74. Gechev, T.S.; Gadjev, I.Z.; Hille, J. An extensive microarray analysis of AAL-toxin-induced cell death in Arabidopsis thaliana brings new insights into the complexity of programmed cell death in plants. Cell. Mol. Life Sci. 2004, 61, 1185-1197.

75. Tanaka, T.; Abbas, H.K.; Duke, S.O. Structure-dependent phytotoxicity of fumonisins and related compounds in a duckweed bioassay. Phytochemistry 1993, 33, 779-785. 
76. Shi, L.; Bielawski, J.; Mu, J.; Dong, H.; Teng, C.; Zhang, J.; Yang, X.; Tomishige, N.; Hanada, K.; Hannun, Y.A.; Zuo, J. Involvement of sphingoid bases in mediating reactive oxygen intermediate production and programmed cell death in Arabidopsis. Cell Res. 2007, 17, 1030-1040.

77. Brown, M.S.; Akopiants, K.; Resceck, D.M.; McArthur, H.A.I.; McCormick, E.; Reynolds, K.A. Biosynthetic origins of the natural product, thiolactomycin: A unique and selective inhibitor of type II dissociated fatty acid synthases. J. Am. Chem. Soc. 2003, 125, 10166-10167.

78. Focke, M.; Feld, A.; Lichtenthaler, H.K. Effect of thiolactomycin on de novo fatty acid biosynthesis in plants. Z. Naturforsch. 1990, 45C, 518-520.

79. Feld, A.; Kobek, K.; Lichtenthaler, H.K. Inhibition of de novo fatty-acid biosynthesis in isolated chloroplasts by different antibiotics and herbicides. Z. Naturforsch. 1989, 44C, 976-978.

80. Feld, A.; Kobek, K.; Litchtenthaler, H.K. Inhibition of fatty-acid biosynthesis in isolated chloroplasts by the antibiotics cerulenin and thiolactomycin. Brighton Crop Prot. Conf. Weeds 1989, 2, 479-486.

81. Weber, H.A.; Gloer, J.B. Interference competition among natural fungal competitors: An antifungal metabolite from the coprophilous fungus Preussia Fleischhakii. J. Nat. Prod. 1988, $51,879-883$.

82. Stierle, A.; Upadhyay, R.; Strobel, G. Cyperine, a phytotoxin produced by Ascochyta cypericola, a fungal pathogen of Cyperus rotundus. Phytochemistry 1992, 30, 2191-2192.

83. Venkatasubbaiah, P.; van Dyke, C.G.; Chilton, W.S. Phytotoxic metabolites of Phoma sorghina, a new foliar pathogen of pokeweed. Mycologia 1992, 84, 715-723.

84. Dayan, F.E.; Ferreira, D.; Wang, Y.-H.; Khan, I.A.; McInroy, J.A.; Pan, Z. A pathogenic fungi diphenyl ether phytotoxin targets plant enoyl (acyl carrier protein) reductase. Plant Physiol. 2008, 147, 1062-1071.

85. Isogai, A.; Fukuchi, N.; Yamashita, S.; Suyama, K.; Suzuki, A. Structures of syringostatin A and syringostatin $\mathrm{B}$, novel phytotoxins produced by Pseudomonas syringae pv. syringae isolated from lilac blights. Tetrahedron Lett. 1990, 31, 695-698.

86. Ballio, A.; Bossa, F.; Collina, A.; Gallo, M.; Iacobellis, N.S.; Paci, M.; Pucci, P.; Scaloni, A.; Segre, A.; Simmaco, M. Structure of syringotoxin, a bioactive metabolite of Pseudomonas syringae pv. syringae. FEBS Lett. 1990, 269, 377-380.

87. Scaloni, A.; Bachmann, R.C.; Takemoto, J.Y.; Barra, D.; Simmaco, M.; Ballio, A. Stereochemical structure of syringomycin, a phytotoxic metabolite of Pseudomonas syringae pv. syringae. Nat. Prod. Lett. 1994, 4, 159-164.

88. Bender, C.L.; Alarcón-Chaidez, F.; Gross, D.C. Pseudomonas syringae phytotoxins: Mode of action, regulation, and biosynthesis by peptide and polyketide synthetases, Microbiol. Mol. Biol. Rev. 1999, 63, 266-292.

89. Goudet, C.; Very, A.A.; Milat, M.L.; Ildefonse, M.; Thibaud, J.B.; Sentenac, H.; Blein, J.P. Magnesium ions promote assembly of channel-like structures from beticolin 0, a non-peptide fungal toxin purified from Cercospora beticola. Plant J. 1998, 14, 359-364.

90. Goudet, C.; Benitah, J.P.; Milat, M.L.; Sentenac, H.; Thibaud, J.B. Cluster organization and pore structure of ion channels formed by beticolin 3, a nonpeptidic fungal toxin. Biophys. J. 1999, 77, 3052-3059. 
91. Tugeon, B.; Baker, S.E. Genetic and genomic dissection of the Cochliobolus heterostrophus Tox 1 locus controlling biosynthesis of the polyketide virulence factor T-toxin. Mol. Plant Microbe Interact. 2006, 19, 219-261.

92. Levings, S.S.; Rhoads, D.M.; Siedow, J.N. Molecular interactions of Bipolaris maydis T-toxin and maize. Can. J. Bot. 1995, 73, S484-S489.

93. Aducci, P.; Marra, M.; Fogliano, V.; Fullone, M.R. Fusicoccin receptors: perception and transduction of the fusicoccin signal. J. Exp. Bot. 1995, 46, 1463-1478.

94. Gomarasca, S.; Vannini, C.; Venegoni, A.; Talarico, A.; Marre, T.; Soave, C. A mutant of Arabidopsis thaliana with a reduced response to fusicoccin. Plant Physiol. 1993, 103, 165-170.

95. Curtis, M.J.; Wolpert, T.J. The victorin-induced mitochondrial permeability transition precedes cell shrinkage and biochemical markers of cell death, and shrinkage occurs without loss of membrane integrity. Plant J. 2004, 38, 244-259.

96. Tada, Y.; Yasuomi, K.; Koh, B.; Betsuyaku, S.; Shinogi, T.; Sakamoto, M.; Ohura, Y.; Hata, S.; Mori, Y.; Tosa, Y.; Mayama, S. Victorin triggers programmed cell death and the defense response via interaction with a cell surface mediator. Plant Cell Physiol. 2005, 46, 1787-1798.

97. Gohbara, M.; Kosuge, Y.; Yamaaki, S.; Kimura, Y.; Suzuki, A.; Tamura, S. Isolation, structures and biological activities of colletotrichins, phytototoxic substances from Colletotrichum nicotianae. Agric. Biol. Chem. 1978, 42, 1037-1043.

98. Duke, S.O.; Gohbara, M.; Paul, R.N.; Duke, M.V. Colletothricin causes rapid membrane damage to plant cells. J. Phytopathol. 1992, 134, 289-305.

99. Sze, H. Nigericin-stimulated ATPase activity in microsomal vesicles of tobacco callus. Proc. Natl. Acad. Sci. USA 1989, 77, 5904-5908.

100. Thuleau, P.; Graziana, A.; Rossignol, M.; Kauss, H.; Auriol, P.; Ranjeva, R. Binding of the phytotoxin zinniol stimulates the entry of calcium into plant protoplasts. Proc. Natl. Acad. Sci. USA 1988, 85, 5932-5935.

101. Iacobellis, N.S.; Bottalico, A. Effects of some trichothecenes produced by Fusarium spp. on electrolyte leakage from tomato leak disk. Phytopathol. Medierranea 1981, 20, 129-132.

102. Au, T.K.; Wallace, S.H.C.; Leung, P.C. The biology of ophioboins. Life Sci. 2000, 67, 733-742.

103. Leung, P.C.; Taylor, W.A.; Wang, J.H.; Tipton, C.L. Role of calmodulin inhibition in the mode of action of ophiobolin A. Plant Physiol. 1985, 77, 303-308.

104. Kuhn, S.; Bussemer, J.; Chigri, F.; Vothknecht, U.C. Calcium depletion and calmodulin inhibition affect the import of nuclear-encoded proteins into plant mitochrondria. Plant J. 2009, $58,694-705$.

105. Chigri, F.; Sol, J.; Vothknecht, U.C. Calcium regulation of chloroplast protein import. Plant J. 2005, 42, 821-831.

106. Vaughn, K.C.; Vaughan, M.A. Mitotic disrupters from higher plants. Am. Chem. Soc. Symp. Ser. 1988, 380, 273-293.

107. Stierle, A.; Strobel, G.; Stierle, D. Taxol and taxane production by Taxomyces andreanae, an endophytic fungus of Pacific yew. Science 1993, 260, 214-216.

108. Strobel, G.; Yang, X.; Sears, J.; Kramver, R.; Sidhu, R.S.; Hess, W.M. Taxol from Pestalotiopsis microspora, an endophytic fungus of Taxus wallachiana. Microbiology 1996, 142, 435-440. 
109. Hoffman, J.C.; Vaughn, K.C. Post-translational tubulin modifications in spermatogeneous cells of the pteridophyte Ceratopteris richardii. Protoplasma 1995, 186, 169-182.

110. Vaughn, K.C.; Vaughan, M.A. Dinitroaniline Resistance in Eleucine Indica may be due to Hyperstabilized Microtubules. In Herbicide Resistance in Weeds and Crops; Caseley, J.C., Cussans, G.W., Atkin, R.K., Eds.; Butterworth-Heinemann Ltd.: Oxford, UK, 1991; pp. $177-186$.

111. Scherlach, K.; Partida-Martinez, L.P.; Dahse, H.M.; Herweck, C. Antimitotic rhizotoxin derivatives from a cultured bacterial endosymbiont of the rice pathogenic fungus Rhizopus microsporus. J. Am. Chem. Soc. 2006, 128, 11529-11536.

112. Partida-Martinez, L.P.; Hertweck, C. Pathogenic fungus harbours endosymbiont bacteria for toxin production. Nature 2005, 437, 884-888.

113. Schmitt, I.; Partida-Martinez, L.P.; Winkler, R.; Voigt, K.; Einax, E.; Dolz, F.; Telle, S.; Woestemeyer, J.; Hertweck, C. Evolution of host resistance in a toxin-producing bacterial-fungal alliance. ISME. J. 2008, 2, 632-641.

114. Cutler, H.G. A Fresh Look at the Wheat Coleoptile Bioassay. In Proceedings of the 11th Annual Meeting of the Plant Growth Regular Society of American, Boston, MA, USA, 29 July-1 August 1984; Volume 11, pp. 1-9.

115. Whitton, B.A. Effect of light on toxicity of various substances to Anacystis nidulans. Plant Cell Physiol. 1968, 9, 23-26.

116. Larson, P.M.; Chen, T.L.L.; Wolniak, S.M. Neomycin reversibly disrupts mitotic progression in stamen hair cells of Tradescantia. J. Cell Sci. 1991, 98, 159-168.

117. Styer, C.H.; Cutler, H.G. Effects of moniliformin on mitosis in maize (Zea mays L.). Plant Cell Physiol. 1984, 25, 1077-1082.

118. Wyss, R.; Tamm, C.; Vederas, J.C. Differential hydrogen exchange during biosynthesis of cytochalasins B and D. Helv. Chim. Acta 1980, 63, 1538-1541.

119. Yang, C.-J.; Zhai, Z.-X.; Guo, Y.-H.; Gao, P. Effects of acetylcholine, cytochalasin B and amiprophos-methyl on phloem transport in radish (Raphanus sativa). J. Integr. Plant Biol. 2007, 49, 550-550.

120. Walton, J.D. HC-toxin. Phytochemistry 2006, 67, 1406-1413.

121. Lukens, J.H.; Durbin, R.D. Tagetitoxin inhibits RNA synthesis directed by RNA polymerases from chloroplasts and Escherichia coli. J. Biol. Chem. 1990, 265, 493-498.

122. Steinberg, T.H.; Matthews, D.E.; Durbin, R.D.; Burgess, R.R. Tagetitoxin: A new inhibitor of eukaryotic transcription by RNA polymerase III. J. Biol. Chem. 1990, 265, 499-505.

123. Steinberg, T.H.; Burgess, R.R. Tagetitoxin inhibition of RNA polymerase III transcription results from enhanced pausing at discrete sites and is template-dependent. J. Biol. Chem. 1992, 267, 20204-20211.

124. Nakajima, M.; Itoi, K.; Takamatsu, Y.; Kinoshita, T.; Okazaki, T.; Kawakubo, K.; Shindo, M.; Honma, T.; Tohjigamori, M.; Haneishi, T. Hydantocydin: A new compound with herbicidal activity from Streptomyces hygroscopicus. J. Antiobiot. 1991, 44, 293-300.

125. Heim, D.R.; Cseke, C.; Gerwick, B.C.; Murdoch, M.G.; Green, S.B. Hydantocidin: A possible pro-herbicide inhibiting purine biosynthesis at the site of adenylosuccinate synthetase. Pestic. Biochem. Physiol. 1996, 55, 210-217. 
126. Siehl, D.L.; Subramanian, M.V.; Walters, E.W.; Lee, S.F.; Anderson, R.J.; Toschi, A.G. Adenylosuccinate synthetase: Site of action of hydantocidin, a microbial phytotoxin. Plant Physiol. 1996, 110, 753-758.

127. Fonne-Pfister, R.; Chemla, P.; Ward, E.; Girardet, M.; Kreuz, E.; Honzatko, R.B.; Fromm, H.J.; Schar, H.P.; Grutter, M.G.; Cowan-Jacob, S.W. The mode of action and the structure of a herbicide in complex with its target: Binding of activated hydantocidin to the feedback regulation site of adenylsuccinate synthetase. Proc. Natl. Acad. Sci. USA 1996, 93, 9431-9436.

128. Cseke, C.; Gerwick, B.C.; Crouse, G.D.; Murdoch, M.G.; Green, S.B.; Heim, D.R. $2 \alpha$-phosphohydantocidin: The in vivo adenylosuccinate synthetase inhibitor responsible for hydantocidin phytotoxicity. Pestic. Biochem. Physiol. 1996, 55, 210-217.

129. Walters, E.W.; Lee, S.F.; Niderman, T.; Bernasconi, P.; Subramanian, M.V.; Siehl, D.L. Adenylosuccinate synthetase from maize. Purification, properties, and mechanism of inhibition by 5'-phosphohydantocidin. Plant Phyisol. 1997, 114, 549-555.

130. Schmitzer, P.R.; Graupner, P.R.; Chapin, E.L.; Fields, S.C.; Gilbert, J.R.; Peacock, C.L.; Gerwick, B.C. Ribofuranosyl triazolone: A natural product herbicide with activity on adenylosuccinate synthetase following phosphorylation. J. Nat. Prod. 2000, 63, 777-781.

131. Daub, M.E.; Hangarter, R.P. Light-induced production of singlet oxygen and superoxide by the fungal toxin, cercosporin. Plant Physiol. 1983, 73, 855-857.

132. Tabuchi, H.; Tajimi, A.; Ichihara, A. (+)-Isocercosporin, a phytotoxic compound isolated from Scolecotrichum grammis Fuckel. Agric. Biol. Chem. 1991, 55, 2675-2676.

133. Liao, H.L.; Chung, K.R. Genetic dissection defines the roles of elsinochrome phytotoxin for fungal pathogenesis of the citrus pathogen Elsinoe fawcettii. Mol. Plant Microbe Interact. 2008, 21, 469-479.

134. Daub, M.E.; Herrero, S.; Chung, K.-R. Photoactivated perylenequinone toxins in fungal pathogenesis of plants. FEMS Microbiol. Lett. 2005, 252, 197-206.

135. Daub, M.E. The fungal photosensitizer cercosporin and its role in plant disease. Amer. Chem. Soc. Symp. Ser. 1987, 339, 271-280.

136. Hieser, I.; Hess, M.; Schmidtke, K.U.; Vogler, U.; Meithbauer, S.; Liebermann, B. Fatty acid peroxidation by rubellin $\mathrm{B}, \mathrm{C}$ and $\mathrm{D}$, phytotoxins produced by Ramularia collo-cygni (Sutton et Waller). Physiol. Mol. Plant Pathol. 2004, 64, 135-143.

137. Harrington, P.M.; Singh, B.K.; Szamosi, I.T.; Birk, J.H. Synthesis and herbicidal activity of cyperin. J. Agric. Food Chem. 1995, 43, 804-808.

138. Kahn, A.; Kannangara, C.G. Gabaculine-resistant mutants of Chlamydomonas reinhardtii with elevated glutamate 1-semialdehyde aminotransferase activity. Carlsberg Res. Commun. 1987, 52, 73-81.

139. Allison, G.; Gough, K.; Rogers, L.; Smith, A. A suicide vector for allelic recombination involving the gene for glutamate 1-semialdehyde aminotransferase in the cyanobacterium Synechococcus PCC 7942. Mol. Gen. Gen. 1997, 255, 392-399.

140. Werck-Reichhart, D.; Jones, O.T.; Durst, F. Haem synthesis during cytochrome P-450 induction in higher plants. 5-Aminolaevulinic acid synthesis through a five-carbon pathway in Helianthus tuberosis tuber tissues aged in the dark. Biochem. J. 1988, 249, 473-480. 
141. May, T.B.; Guikema, J.A.; Henry, R.L.; Schuler, M.K.; Wong, P.P. Gabaculine inhibition of chlorophyll biosynthesis and nodulation in Phaseolus lunatus L. Plant Physiol. 1987, 84, 1309-1313.

142. Gardner, G.; Gorton, H.L. Inhibition of phytochrome synthesis by gabaculine. Plant Physiol. 1985, 77, 540-543.

143. Matson, R.S.; Kimura, T. Ferredoxin biosynthesis in Euglena gracilis. Biochim. Biophys. Acta 1976, 442, 76-87.

144. Ohta, N.; Sager, R. Identification of a chloroplast ribosomal protein altered by a chloroplast mutation in Chlamydomonas. J. Biol. Chem. 1975, 250, 3655-3659.

145. Torregrosa, L.; Peros, J.-P.; Bouquet. Effect of hygromycin, kanamycin and phosphinothricin on the embryonic callus development and axillary micropropagation of Vitus vinifera L. Acta Hort. 1998, 528, 401-406.

146. Joersbo, M.; Okkels, F.T. Calcium reduces toxicity of aminoglycoside antibiotics in sugar beet explants in vitro. Phyiol. Plant. 1996, 97, 245-250.

147. Spahn, C.M.; Prescott, C.D. Throwing a spanner in the works: Antibiotics and the translation apparatus. J. Mol. Med. 1996, 74, 423-439.

148. Umezawa, H.; Aoyagi, T.; Tanaka, T.; Suda, H.; Okuyama, A.; Naganawa, H.; Hamada, M.; Takeuchi, T. Production of actinonin, an inhibitor of aminopeptidase M, by actinomycetes. J. Antibiot. 1985, 38, 1629-1630.

149. Hou, C.-X.; William, M. Actinonin-induced inhibition of plant peptide deformylase: a paradigm for the design of novel broad-spectrum herbicides. Am. Chem. Soc. Symp. Ser. 2006, 927, $243-254$.

150. Hou, C.-X.; Dirk, L.M.A.; Pattanik, S.; Das, N.C.; Maiti, I.B.; Houtz, R.L.; Williams, M.A. Plant peptide deformylase: A novel selectable marker and herbicide target based on essential cotranslational chloroplast protein processing. Plant Biotechnol. J. 2007, 5, 275-281.

151. Fernandez-San Milan, A.; Obregon, P.; Veramendi, J. Over-expression of peptide deformylase in chloroplasts confers actinonin resistance, but is not a suitable selective marker system for plastid transformation. Transgenic Res. 2011, 20, 613-624.

152. McLaughlin, J.E.; Bin-Umer, M.A.; Tortora, A.; Mendez, N.; McCormic, S.; Turner, N.E. A genome-wide screen in Saccharomyces cerevisiae reveals a critical role for the mitochondria in the toxicity of a trichothecene mycotoxin. Proc. Natl. Acad. Sci. USA 2009, 106, 21883-21888.

153. Di, R.; Blechl, A.; Dill-Macky, R.; Tortora, A.; Turner, N.E. Expression of a truncated form of yeast ribosomal protein L3 in transgenic wheat improves resistance to Fusarium head blight. Plant Sci. 2010, 178, 374-380.

154. Larsen, S.H.; Berry, D.M.; Paschal, J.W.; Gilliam, J.M. 5-Hydroxymethylblasticidin S and blasticidin S from Streptomyces setonii culture A83094. J. Antibiot. 1989, 42, 470-471.

155. Nishimura, M.; Matsuo, H.; Nakamura, A.; Sugiyama, M. Purification and characterization of a puromycin-hydrolyzing enzyme from blastocidin S-producing Streptomyces morookaensis. J. Biochem. 1998, 123, 247-252.

156. Scacchi, A.; Bortolo, R.; Cassani, G.; Pirali, G.; Nielson, E. Detection, characterization, and phytotoxic activity of the nucleoside antibiotics, blasticidin $\mathrm{S}$ and 5-hydroxylmethyl-blasticidin S. J. Plant Growth Regul. 1992, 11, 39-46. 
157. Petropoulos, A.D.; Xaplanteri, M.A.; Dinos, G.P.; Wilson, D.N.; Kalpaxis, D.L. Polyamines affect diversely the antibiotic potency: Insight gained from kinetic studies of the blasticidin $\mathrm{S}$ and spiramycin interactions with functional ribosomes. J. Biol. Chem. 2004, 279, 26518-26525.

158. Kalpaxis, D.L.; Dimitrios, L.; Theocharis, D.A.; Coutsogeorgopoulos, C. Kinetic studies on ribosomal peptidyltransferase. The behavior of the inhibitor blasticidin S. Fed. Eur. J. Biochem. 1986, 154, 267-271.

159. Rodriguez-Foneca, C.; Amils, R.; Garrett, R.A. Fine structure of the peptidyl transferase center on 23 S-like rRNAs deduced from chemical probing of anitbiotic-ribosome complexes. J. Mol. Biol. 1995, 247, 224-235.

160. Rouxel, T.; Chupeau, Y.; Fritz, R.; Kollmann, A.; Blouquet, J.F. Biological effects of sirodesmin PL, a phytotoxin produced by Leptosphaeria maculans. Plant Sci. 1988, 57, 45-53.

161. Chai, C.L.L.; Waring, P. Redox sensitive epidithiodioxopiperazines in biological mechanisms of toxicity. Redox Rep. 2000, 5, 257-264.

162. Wright, J.M. Phytotoxic effects of some antibiotics. Ann. Bot. 1951, 15, 493-499.

163. Tanaka, T.; Hanato, K.; Watanabe, M.; Abbas, H.K. Isolation, purification and identification of 2,5-anhydro-D-glucitol as a phytotoxin from Fusarium solanii. J. Nat. Toxins 1996, 5, 317-329.

164. Dayan, F.E.; Rimando, A.M.; Tellez, M.R.; Scheffler, B.E.; Roy, T.; Abbas, H.K.; Duke, S.O. Bioactivation of the fungal phytotoxin 2,4-anhydro-D-glucitol by glycolytic enzymes is an essential component of its mechanism of action. Z. Naturforsch. 2002, 57C, 645-653.

165. Graupner, P.R.; Carr, A.; Clancy, E.; Gilbert, J.; Bailey, K.L.; Derby, J.A.; Gerwick, B.C. The macrocidins: Novel cyclic tetramic acids with herbicidal activity produced by Phoma macrostoma. J. Nat. Prod. 2003, 66, 1558-1561.

166. Graupner, P.R.; Gerwick, B.C.; Siddall, T.L.; Carr, A.W.; Clancy, E.; Gilbert, J.R.; Bailey, K.L.; Derby, J.A. Chlorosis inducing phytotoxic metabolites: New herbicides from Phoma macrostoma. Am. Chem. Soc. Symp. Ser. 2006, 927, 37-47.

167. Okuhara, M.; Kuroda, Y.; Goto, T.; Okamoto, M.; Terano, H.; Kohsaka, M.; Aoki, H.; Imanaka, H. Studies on new phosphonic acid antibiotics. III. Isolation and characterization of FR-31564, FR-32863 and FR-33289. J. Antibiot. 1980, 33, 24-28.

168. Lichtenthaler, H.K.; Zeidler, J.; Schwender, J.; Muller, C. The non-mevalonate isoprenoid biosynthesis of plants as a test system for new herbicides and drugs against bacteria and the malaria parasite. Z. Naturforsch. 2000, 55C, 305-313.

169. Zhen, R.-G.; Singh, B.K. From inhibitors to target site genes and beyond-herbicidal inhibitors as powerful tools for functional genomics. Weed Sci. 2001, 49, 266-272.

170. Jacyno, J.M.; Cutler, H.G.; Roberts, R.G.; Waters, R.M. Effects on plant growth of the HMG-CoA synthase inhibitor, 1233A/F-244/L-659,699, isolated from Scopulariopsis candidus. Agric. Biol. Chem. 1991, 55, 3129-3131.

171. Omura, S.; Tomoda, H.; Kumagai, H. Potent inhibitory effect of antibiotic 1233A, which specifically blocks 3-hydroxy-3-methylglutaryl coenzyme A synthase, on cholesterol biosynthesis. J. Antibiot. 1987, 40, 1356-1357. 
172. Greenspan, M.D.; Yudkovitz, J.B.; Lo, C.Y.; Chen, J.S.; Alberts, A.W.; Hunt, V.M.; Chang, M.N.; Yang, S.S.; Thompson, K.L.; Chiang, Y.C.; Chabala, J.C.; Monaghan, R.L.; Schwartz, R.L. Inhibition of hydroxymethylglutaryl-coenzyme A synthase by L-659,699. Proc. Natl. Acad. Sci. USA 1987, 84, 7488-7492.

173. Duke, S.O.; Baerson, S.R.; Gressel, J. Genomics and Weeds: A synthesis. In Weedy and Invasive Plant Genomics; Stewart, C.N., Ed.; Blackwell Publishing: Singapore, 2009; pp. 221-247.

174. Gerwick, B.C. Thirty years of herbicide discovery: Surveying the past and contemplating the future. Agrow 2010, VII-IX.

(C) 2011 by the authors; licensee MDPI, Basel, Switzerland. This article is an open access article distributed under the terms and conditions of the Creative Commons Attribution license (http://creativecommons.org/licenses/by/3.0/). 